\title{
Role of IASLIC in Developing Computer Skills Among LIS Professionals in India
}

\author{
J. N. Satpathi ${ }^{1}$ \\ Chitra Satpathi ${ }^{2}$ \\ Gurudas Ghosh ${ }^{3}$
}

\begin{abstract}
:
Indian Association of Special Libraries \& Information Centres (IASLIC) is a pioneer association in India that has been working for the development of library and information services since its inception in 1955. IASLIC has adopted various multifaceted activities for the healthy growth of library services and to safeguard the interest of library professionals as well as library users. IASLIC has been working to resolve various discrepancies particularly in selection of hardware and library software packages, interchange formats, training for digitization and to set a standard that ideally suits the most of the libraries in our country. After introduction of computer applications in LIS in the later part of 1980s, libraries urgently required adequate computer trained workforce to perform library services. Understanding the scenario and anticipating the future needs, IASLIC has been giving prime importance to manpower development programme. A brief overview of IASLIC activities like Conferences, Seminars, Workshops, Study Circles, Special Interest Groups, publications, lectures by experts, etc. related to computer training organized by IASLIC and its role as a advisory organization to Government for making policies related to LIS has also described in this article.
\end{abstract}

Keywords: IASLIC, Developing countries, LIS professionals, India

\section{Introduction}

Library is a significant characteristic of civilization and we find a large number of libraries in any civilized society irrespective of countries, race and communities. India is not an exception. We find a good number of modern libraries in both government and private sectors, with all modern facilities. But it is not a common picture of library service in India. It is found that libraries are operational in different part of the country with their own systems and resources.

\footnotetext{
1 President, Indian Association of Special Libraries \& Information Centres, Email: satpathijn@rediffmail.com

${ }^{2}$ Librarian, Muralidhar Girls’College, Kolkata, India.Email: chitra_satpathi@rediffmail.com

${ }_{3}$ Technical Assistant (Library), S N Bose National Centre for Basic Sciences, Kolkata, India. Email: gurudasghosh28@gmail.com
} 


\section{Bangladesh Journal of Library and Information Science}

Librarians are trying to develop their own library with the guidelines of their governing authority. To ensure better library services to our society, it is very important to think of the betterment of library service, correct and timely policies and certainly the betterment of the professional skill for all the libraries in the country instead of developing of one particular library. Here lies the importance of Library Associations those can coordinate all the libraries nationwide and help the LIS profession to uplift its skill and expertise. If the professionals of the country having their active participation and support accept a professional Association, the Association practically becomes the key force to influence the Government as well as the society. It is natural because a professional organiasation can understand the problems, prospects and the need of the hour better than any other governing authority of the library.

\section{Objectives of the Association}

The objective of a Library Association may be divided into three basic categories:

\section{(i) Societal objective:}

Library Movement is a social welfare activity that develops spontaneously as a product of collective initiative to development library awareness among all sections of the society with ultimate objective of hastening the process of social, cultural and economic growth of the society. Objectives of Library Association further include promotion of reading

\section{(ii) Professional objective:}

Distinct from a general occupation, a learned profession has a philosophy to render a public service with theories of action underlying specialized knowledge and skills necessitating education, research, development and application.

\section{(iii) Political objective:}

When libraries are set up and run by legislative or administrative laws, a Library Association has to keep vigil on such actions and act as a 'watch dog' to safeguard the interest of LIS professionals as well as the library user community.

\section{(iv) Development of National Information Service in India}

IASLIC was established in 1955 a non-profit making national professional body with the following objectives:

- to promote quality of library \& Information services

- coordinate the activities

- improve the technical efficiency of the professionals

- to act as a center of research and studies in special libraries etc.

\section{Scenario of Computer Application in LIS}

Application of computer in LIS profession started in 1980s although at a preliminary level. Significantly, during the next two decades, library and information services promptly switched over to computerized system without having the scope and time for training adequate manpower to support it. It needs no explanation that there was a gap between the supply and demand of computer literate workforce in the LIS profession. Not only that, it is observed that newly passed out students from LIS schools also require some special hands-on-training to 
gain expertise and confidence. The present days challenges of LIS professionals are IT applications, web based library services, networking and server based services, e-consortia and legal issues related to cyber activities, creating digital repository, use of open source software and so on.

IASLIC could anticipate the future needs of LIS professionals and to bridge the 'gap' between the demand and supply of computer literate human resources, several programmes have been taken. IASLIC has by and large fulfilled its role coordinating and harnessing the professional responsibilities in bringing out a harmonious development of the profession and library information services in India. The main activities of the IASLIC in this direction are;

- holding annual seminars and conferences in different parts of the country

- conducting study circle meetings at its headquarters and some state branches

- organizing special short term training courses

- bring out serial publications, monographs and pamphlets etc,

\section{Conferences \& Seminars}

The IASLIC holds a biennial seminar and conference in alternate years through this forum the Association keeps with the members in different parts country, rotating the venue in various research and academic institutions. Special attention was given on computer training after introduction of computer in LIS in India. From the table below it clearly indicates that special attention was given on computer training after introduction of computer in LIS.

\section{CONFERENCES}

\begin{tabular}{|l|c|l|c|}
\hline S1 & Year & Topic & Place \\
\hline 1 & 1977 & Planning of national network & Dharwar \\
\hline 2 & 1981 & $\begin{array}{l}\text { I. Organisation of data services in India } \\
\text { II. Users education and training programmes }\end{array}$ & New Delhi \\
\hline 3 & 1989 & $\begin{array}{l}\text { Manpower planning for library and } \\
\text { information centers in India }\end{array}$ & Kurukshetra \\
\hline 4 & 1993 & $\begin{array}{l}\text { Information management in library and information } \\
\text { centers in India }\end{array}$ & Lucknow \\
\hline 5 & 1995 & $\begin{array}{l}\text { Information technology products of 1990s and library } \\
\text { and information centers }\end{array}$ & Agra \\
\hline 6 & 1997 & $\begin{array}{l}\text { Information superhighway: its impact on } \\
\text { library and information services in India }\end{array}$ & $\begin{array}{l}\text { Dehra Dun } \\
\text { emerging information society }\end{array}$ \\
\hline 7 & 1999 & Chennai \\
\hline 8 & 2001 & Content management in India in digital environment & Thiruvananthapuram \\
\hline 9 & 2003 & $\begin{array}{l}\text { Knowledge management in special libraries in } \\
\text { digital environment }\end{array}$ & New Delhi \\
\hline 10 & 2005 & LIS profession in India: vision for 2010 & Bhubaneswar \\
\hline 11 & 2007 & Digital Media \& Library Information Services & \\
\hline 12 & 2009 & Library / Information users in Digital Era & \\
\hline
\end{tabular}




\section{Bangladesh Journal of Library and Information Science}

In this regard, it should be mentioned that National Conference on "Planning of national network" that took place in Dharwar (Karnataka) in the year 1977 recommended some important proposals and guidelines those in later years implemented by UGC and Govt. of India to promote library networking as well as to build national information policy. In the Conferences/Seminars organized once a year, papers are invited in the following six

\section{SEMINARS}

\begin{tabular}{|l|l|l|c|}
\hline Sl & Year & Topic & Place \\
\hline 1 & 1978 & $\begin{array}{l}\text { I. Standardization of techniques and procedures } \\
\text { for information handling } \\
\text { II. Library and Information system for rural development }\end{array}$ & Chennai \\
\hline 2 & 1980 & $\begin{array}{l}\text { I. Role of information centers in technology transfer. } \\
\text { II. Role of state-level and national library associations } \\
\text { in library development of India }\end{array}$ & Nagpur \\
\hline 3 & 1982 & Information services in India & Kanpur \\
\hline 4 & 1992 & Information retrieval: models and techniques & Annamalainagar \\
\hline 5 & 1994 & Networking of libraries: Problems and prospects & Mumbai \\
\hline 6 & 1996 & $\begin{array}{l}\text { Meeting the information challenge for development } \\
\text { and self-sufficiency }\end{array}$ & Kolkata \\
\hline 7 & 2000 & Library and information profession at the cross-roads & Bhopal \\
\hline 8 & 2002 & Digital information systems and services & Katiala \\
\hline 9 & 2004 & Information Support for Rural Development & New Delhi \\
\hline 10 & 2006 & Open source Movement - Asian perspective & Kolkata \\
\hline 11 & 2008 & Library Profession in search of a new paradigm & \\
\hline
\end{tabular}

Special Interest Groups (SIGs):

- LIS Education

- Humanities

- Social Science

- Informatics

- Industrial Information

- Computer Application

Emphasis is given to computer and information technology in the SIGs for the development of computer skill among LIS processionals. 


\section{Workshops/Training}

Trained manpower is an essential pre-requisite in the evolution of an effective information service. Accordingly, IASLIC conducts short-term courses on special subjects. Such short tern courses are the essential functions of a professional association, both to supplement the full time academic courses for students and to ensure continuing education for practicing library professionals.Understanding the demand from the professionals, IASLIC organized the following workshops to develop computer skill among LIS professionals.

\section{WORKSHOPS/TRAININGS}

\begin{tabular}{|c|c|c|}
\hline Main Subject & $\begin{array}{c}\text { Training programes } \\
\text { (with numbers in parentheses) }\end{array}$ & Total No. \\
\hline Application of IT & $\begin{array}{l}\text { Computer application [2] } \\
\text { Library software [10] } \\
\text { WebPages designing [1] } \\
\text { D-Space [2] } \\
\text { Resource sharing [1] } \\
\text { Information management technology [3] }\end{array}$ & 19 \\
\hline $\begin{array}{l}\text { Information Processing } \\
\text { and Retrieval }\end{array}$ & $\begin{array}{l}\text { Indexing [3] } \\
\text { Thesaurus [4] } \\
\text { Information access [1] }\end{array}$ & 8 \\
\hline Information Service & $\begin{array}{l}\text { Information consolidation [1] } \\
\text { Access to social science information [2] }\end{array}$ & 3 \\
\hline Management & $\begin{array}{l}\text { Management [2] } \\
\text { Marketing [1] } \\
\text { Customer satisfaction [1] } \\
\text { Reprography [1] } \\
\text { Conservation \& Preservation [2] }\end{array}$ & 7 \\
\hline $\begin{array}{l}\text { Information } \\
\text { Communication }\end{array}$ & Audio-visual [3] & 3 \\
\hline Library \& Society & $\begin{array}{l}\text { Special librarianship \& documentation } \\
\text { (1 year diploma) [1] }\end{array}$ & 1 \\
\hline
\end{tabular}

\section{Study Circles}

Apart from the above-mentioned conferences, seminars and workshops, IASLIC also conducted a series of Study Circle and invited eminent speakers expert in different fields on a specialized topic related to LIS. From the statistics of study circles, it needs no explanation that emphasis has been given on the issue of manpower development in LIS profession specially computer application in LIS environment. These meetings help to promote the ability of 


\section{Bangladesh Journal of Library and Information Science}

members to discuss problem and issues and also serve as a system of harnessing the intellectual growth in the profession.

\section{Study Circles}

\begin{tabular}{|l|c|}
\hline Main Subject & Total Number of study circle \\
\hline Application of IT in LIS & 49 \\
\hline Information Processing and Retrieval & 52 \\
\hline Information Services & 70 \\
\hline Management & 29 \\
\hline Information \& Communication & 4 \\
\hline Library \& Society & 88 \\
\hline Total No. of Study Circles & $\mathbf{2 9 2}$ \\
\hline
\end{tabular}

The above topics of IASLIC Study Circles reflect the trend of changes after introduction of computer in library. The changes were wisely anticipated by IASLIC and tried its best to train the LIS professionals on the new developments, which were the 'need of the hour'. The study circles are not limited to lectures by experts but also included the commercial enterprises to aware LIS professionals about new IT products and services. In this way, IASLIC opened a new platform to bridge the gap between conventionally trained LIS professionals and the state of art technology introduced in the market. Further, the study circles are not limited to the problems and prospects of LIS in India, but also extended to outer world. Speakers from USA, UK, Japan, Russia etc. delivered lectures in those study circles. For example, In the $226^{\text {th }}$ Study Circle Meeting in 1996, Mr. Badiduddin Nazir was invited from Bangladesh and talked on the topic "From Hypermedia to information Super Highway: National Book Policy of Bangladesh. This effort certainly leads to build a global LIS community with greater awareness.

\section{IASLIC Publications}

For commutation of professional thinking and dissemination of knowledge, the publication activity is of paramount importance. The association publishes books, pamphlets, journals and conference/seminars paper. Of particular interest among the publications are:

i. Serial publications: IASLIC Bulletin (Quarterly), Indian Library Science Abstract (ILSA), (Yearly), IASLIC Newsletter (Monthly).

ii. Special Publications: Volumes containing working papers, proceedings and recommendations on different subjects of seminars and conferences.

22 Seminar 27 Conference had taken place different parts of the country.

iii. Other publications: IASLIC brought out a few monographs and technical papers. Though the Association has undoubtedly a creditable record of publication, but there is still much that it can do in this regard. 


\section{Awards \& Encouragements}

To promote Library \& Information service and to motivate the LIS professionals in the country, members of IASLIC has introduced 5 awards those are awarded annually.

- Dr S. M. Ganguly award for Librarian of the year

- Mr Subba Rao award for Best Article of the year (published in the IASLIC Bulletin \& IASLIC Conference/Seminar Proceedings)

- Prof Prabir Roychudhury \& Amita Roychoudhury -award for Best Library \& Information Science Teacher of the year

- Smt A. Satyavathi \& Prof A A N Raju- Best Young Library \& Information Science Teacher award of the year

- Prof. A K. Mukherjee award Lifetime Achievement for Retired Librarian.

Enormous encouragement in the activities has been found among the LIS professionals in India regarding the above said awards.

\section{Special Lectures:}

IASLIC organizes two lectures annually:

i. Ranganathan Lecture delivers by senior library \& information professionals.

ii. Dr R.C. Gupta. Annual Special Lecture delivers by eminent personalities in the society.

\section{Status of LIS professionals}

In the last few decades the scenario of Special Libraries in India has changed dramatically and drastically. The librarians have been redefining their roles and responsibilities according to the need of the hours - from merely Book Keeper to Librarian to Documentalist to Information Scientist to Knowledge Manager. This may be noted that importance of library \& information services have gained in recent times, not only in academic fields, but also in other areas, i. e. IT, industry, trade, research etc.

To justify the demands of LIS professionals, IASLIC has been negotiating with government with various issues related to the facilities of LIS professionals in the country. At the same time, it would not be irrelevant to say that there are a large number of LIS professionals working in private sectors, which are neither organized nor paid adequately for their services. IASLIC always try to do its best for their betterment in all respects but the main problem is LIS professionals working in private sector are not united.

\section{JOCLAI (Joint Council of Library Association in India)}

On the basis of a recommendations made at IASLIC National Seminar, Nagpur in 1980 JOCLAI was formed in 1982 at ILA in New Delhi. JOCLAI comprises the national level library associations like ILA, IASLIC, MLAI, IATLIS and other state library associations in the country for coordinating all LIS professional under one umbrella. A framework for the 


\section{Bangladesh Journal of Library and Information Science}

operation of JOCLAI was also been adopted in 1986. The activities of JOCLAI were declined for time being. However, to revive JOCLAI in its full strength, IASLIC has formulated strategies in the $27^{\text {th }}$ IASLIC National Conference very recently. Following recommendations have been made in this regard:

i. A National Council of LIS Education and Research to be set up.

ii. An accreditation mechanism be created for LIS Degree on the lines of AICTE, MCI etc. and compulsory registration of LIS professionals be insisted.

iii. The basic degree in LIS to be made compulsory for top posts in LIS as in medical and engineering field.

\section{Discrepancies related to IT applications}

Computerized information service importantly depends on the software, hardware and the standards maintained in the system. Both the hardware and software in the field of computer have changed frequently. Not only that, different hardware and software packages are produced, available and used in regional basis depending on the needs of local users. This practice inevitably created the problem of uniformity in software packages, languages and operating procedures. Libraries have been facing the problem of 'lack of uniformity' since the introduction of computer. For example we find many library software like WINISIS (by UNESCO), SOUL (by INFLIBNET), LIBSYS (Libsys Corporation), e-Granthalaya (by NIC) and many more. Formats and operating procedures vary from package to package and training manpower for it becomes difficult. Moreover, if a library staff transferred or joins in another computerized library he/she needs to learn the new computerized system. IASLIC has been working to resolve various discrepancies particularly in selection of hardware and library software packages, interchange formats, training for digitization and to set a standard that ideally suits the most of the libraries in our country. In this connection, it may be mentioned that the recent Conference "Library / Information users in Digital Era" that held in Bhubaneswar this year focused on it to chalk out the future actions.

\section{Conclusion}

The IASLIC has rightly chosen to provide conscious support to the national effort in evolving an effective library and information service in the country. The collective thinking and the national debate on vital aspects of national information services in a digital environment provided but the IASLIC through the platform of seminars, conferences, SIG meetings/training program, study circle etc should provide sound guidelines to the national planners and policy-makers. The contribution made by the IASLIC and its future potential should be fully realized and should be represented on all policy-making bodies involved in the development of a national information system.

A national professitional association's vitality depends largely on the wide participation and active contribution of its members. It is imperative that the members at various centers organize themselves into active groups to conducts study circle meetings, short term courses, workshops and other such activities. Such groups would provide the nucleus for opening the branch chapter, which the IASLIC envisages as its future course of development.

It should also be admitted that there are some issues associated to develop human resources like mental rejection of staff, trade unions, lack of interest from the higher authority etc. 
However, those issues can effect, but cannot stop the process to professional developments. The growth and increasing popularity of IASLIC during 1955 to the end of 2009 is the proof of this truth.

\section{References:}

IASLIC : Ninth IASLIC Seminar : Role of State-Level and National Library Associations in Library Development of India.. Nagpur, 1980

IASLIC: Management in Library and Information Centres in Indian; $18^{\text {th }}$ IASLIC Conference, Kurukshetra, 1991.

IASLIC: Open Source Movement - Asian Perspective. XXII IASLIC Seminar, Roorkee, 2006.

Singh Anil: Library Automation and Networking Software in India: an overview. Information Development, Vol.19 No.1, 2003, pp.51-56.

Dasgupta A and Satpathi J N (Eds.) : IASLIC: Challenges and Prospects. Indian Association of Special Libraries \& Information Centres, Kolkata, 2007.

Gokul A N: Paradigm shifts in LIS Profession and Implimentations of the National Knowledge Commission Proc. Of 23 ${ }^{\text {rd }}$ National Seminar of IASLIC, Kolkata, 2008. 